Г.В. Пєвцов ${ }^{1}$, М.М. Олещук ${ }^{2}$

${ }^{1}$ Харківський національний університет Повітряних Сил ім. І. Кожедуба, Харків

${ }^{2}$ Командування Повітряних Сил Збройних Сил Украӥни, Вінниия

\title{
АНАЛІЗ СПРОМОЖНОСТЕЙ ОГЛЯДОВИХ РЛС РТВ ЩОДО ВИЯВЛЕННЯ, СУПРОВОДЖЕННЯ ТА ІДЕНТИФІКАЦІЇ БЕЗПІЛОТНИХ ЛІТАЛЬНИХ АПАРАТІВ
}

3 урахуванням досвіду ведення бойових дій в зоні операції об’єднаних Сил (ООС) проведено аналіз спроможностей оглядових РЛС, які перебувають на озброєнні радіотехнічних військ Повітряних Сил Збройних Сил України, щзодо виявлення, супроводження та ідентифікації безпілотних літальних апаратів (БпЛА) різних типів.

Показано, щуо найгострішою проблемою є проблема виявлення та супроводження міні- та мікроБПЛА (БПЛА поля бою), вирішення якої існуючими радіолокаиійними засобами є неможливим.

Ключові слова: безпілотний літальний апарат, радіотехнічні війська, виявлення, супроводження, ідентифікація.

\section{Вступ}

Постановка проблеми. Характерними рисами сучасної збройної боротьби є масоване застосування безпілотних літальних апаратів (БПЛА) та постійне розширення спектру їх задач [1]. Подальший розвиток технологій штучного інтелекту безумовно спричинить зростання використання БПЛА у майбутніх військових операціях [2-6]. За масштабами застосування найбільш поширеними на сьогодні є БПЛА тактичного призначення та БПЛА поля бою [7-8], виявлення та супроводження яких $€$ надзвичайно складним завданням. Тому пошук ефективних способів виявлення, супроводження та ідентифікації БПЛА з використанням як існуючих, так і нових перспективних засобів $\epsilon$ достатньо актуальною проблемою.

Аналіз останніх досліджень і публікацій. В даний час існує значна кількість публікацій, присвячених різним за фізичними принципами дії засобам виявлення та спостереження БПЛА. Для вирішення задачі виявлення, розпізнавання та вимірювання координат безпілотних літальних апаратів можуть бути використані такі засоби розвідки, як [9-18]:

- засоби оптичної розвідки;

- інфрачервоні засоби;

- акустичні засоби;

- засоби радіотехнічної розвідки;

- радіолокаційні засоби.

Кожен із засобів має свої переваги і недоліки i, отже, не являється універсальним засобом.

В засобах оптичної розвідки [10; 13] здійснюється обробка зображень, одержаних за допомогою оптичних камер. Ця обробка проводиться як тради- ційними методами “комп'ютерного зору” з ручним формуванням ознак БПЛА, так і з використанням підходів, що грунтуються на машинному навчанні [13]. Інфрачервоні засоби виявлення [10] реалізуються 3 використанням тепловізійних камер. Однак значна вартість тепловізійних камер, що мають високу роздільну здатність, поки що обмежує практичне використання означених засобів [14]. Акустичні засоби широко використовуються на практиці при виявленні БПЛА на невеликих (до 150 м) відстанях $[11 ; 15 ; 18]$. Незважаючи на відносну простоту реалізації та достатню інформативність, використання акустичних засобів також обмежено через значні акустичні фонові шуми, особливо в умовах ведення бойових дій. Засоби радіотехнічної розвідки $[12 ; 17]$ $\epsilon$ ефективними засобами виявлення та ідентифікації лише тих об'єктів, які мають на борту джерела радіовипромінювання. Виявлення ними БПЛА, що здійснюють політ в режимі мовчання, є неможливим.

Серед зазначених засобів виявлення, супроводження та ідентифікації БПЛА найбільш ефективними на сьогодні є засоби радіолокаційної розвідки, які теоретично мали б забезпечувати виявлення БПЛА на значних відстанях без істотного впливу погодних умов та часу доби. Проте практика використання існуючого парку РЛС в зоні проведення ООС свідчить про чисельні випадки пропуску та нестійкого супроводження БПЛА різних класів. У зв'язку з цим виникає необхідність в аналізі реальних можливостей існуючих оглядових РЛС щодо виявлення, супроводження та ідентифікації БПЛА різних типів 3 урахуванням їхніх особливостей як об'єктів радіолокації. 
Безпосередньо метою статті є аналіз реальних спроможностей існуючих на озброєнні радіотехнічних військ (РТВ) Повітряних Сил Збройних Сил України оглядових РЛС щодо виявлення, супроводження та ідентифікації безпілотних літальних апаратів.

\section{Виклад основного матеріалу}

1. Характеристика БПЛА як об'єктів радіолокації.

Під безпілотним літальним апаратом (БпЛА)
[8] розуміється літальний апарат без льотчика на борту з дистанційною системою керування певного рівня автоматизації чи такий, що виконує автоматичний політ за заданою заздалегідь програмою. Це надзвичайно широкий клас літальних апаратів різного призначення і можливостей, класифікація яких здійснюється за сімнадцятьма класифікаційними ознаками [8; 19]. Серед усіх класифікаційних ознак найбільш інформативною ознакою їх, як об'єктів радіолокаційної розвідки, є класифікація БПЛА за рівнем застосування та радіусом дії (табл. 1).

Таблиця 1

Зведена класифікація БПЛА за рівнем застосування та бойовим радіусом

\begin{tabular}{|c|c|c|c|c|c|c|c|}
\hline Клас & $\begin{array}{c}\text { Рівень } \\
\text { застосування }\end{array}$ & $\begin{array}{c}\text { Приблизні } \\
\text { розміри } \\
\text { (довжина)× } \\
\text { (ширина)× } \\
\text { (висота), м }\end{array}$ & $\begin{array}{c}\text { Злітна маса, } \\
\text { кг }\end{array}$ & $\begin{array}{c}\text { Висота } \\
\text { польоту, } \\
\text { м }\end{array}$ & $\begin{array}{c}\text { Швидкість, } \\
\text { км/год }\end{array}$ & $\begin{array}{c}\text { Бойовий } \\
\text { радіус }\end{array}$ & $\begin{array}{c}\text { Категорія } \\
\text { БпЛА } \\
\text { держав - } \\
\text { членів } \\
\text { НАТО } \\
\end{array}$ \\
\hline \multirow{3}{*}{ I клас } & $\begin{array}{c}\text { мікро } \\
\text { (тактичні) }\end{array}$ & $0,5 \times 0,5 \times 0,1$ & $\mathrm{~m}<2$ & $<1000$ & $60-100$ & \begin{tabular}{|c|} 
до 5 км \\
(зона прямої \\
видимості) \\
\end{tabular} & micro \\
\hline & $\begin{array}{c}\text { міні } \\
\text { (тактичні } \\
\text { поля бою) } \\
\end{array}$ & $1,5 \times 1,5 \times 0,2$ & $2 \leq \mathrm{m} \leq 15$ & $<5000$ & $80-120$ & \begin{tabular}{|c|} 
більше 5 км \\
(зона прямої \\
видимості) \\
\end{tabular} & $\operatorname{mini}$ \\
\hline & $\begin{array}{c}\text { малі } \\
\text { (тактичні) }\end{array}$ & $2,0 \times 2,0 \times 1,0$ & $15<\mathrm{m}<150$ & $<5000$ & $100-140$ & \begin{tabular}{|c} 
більше 25 \\
км \\
(зона прямої \\
видимості)
\end{tabular} & small \\
\hline II клас & $\begin{array}{c}\text { оперативно- } \\
\text { тактичні }\end{array}$ & $4,0 \times 4,0 \times 1,0$ & $150 \leq \mathrm{m} \leq 600$ & $<5000$ & $100-160$ & \begin{tabular}{|c} 
більше 50 \\
км \\
(зона прямої \\
видимості) \\
\end{tabular} & tactical \\
\hline \multirow[t]{2}{*}{ III клас } & оперативні & $20,0 \times 10,0 \times 4,0$ & \multirow{2}{*}{$m>600$} & $<15000$ & $100-500$ & \begin{tabular}{|c|} 
більше 200 \\
км \\
(поза зоною \\
прямої \\
видимості) \\
\end{tabular} & MALE \\
\hline & стратегічні & $40,0 \times 15,0 \times 5,0$ & & $<20000$ & $250-700$ & $\begin{array}{c}\text { більше } 200 \\
\text { км } \\
\text { (поза зоною } \\
\text { прямої } \\
\text { видимості) }\end{array}$ & HALE \\
\hline
\end{tabular}

Джерело: розроблено авторами з використанням даних [8; 19, Додаток 1].

В означених класифікаціях відсутні такі важливі для радіолокаційного виявлення та супроводження БпЛА характеристики, як ефективна площа розсіювання (ЕПР). У відкритій літературі такі характеристики БпЛА відсутні. Більше того, вони не рекламуються ні виробниками, ні користувачами. Реальні їх значення можна отримати лише експериментально на спеціальних полігонах (або в безлунних камерах) для кожного конкретного типу літального апарату. За відсутності експериментальних даних використовують результати математичного моделювання за методиками, викладеними в [20-22].
На рис. 1 наведені результати моделювання [20] кругових діаграм ЕПР конкретних типів оперативних і стратегічних БпЛА. На кожній діаграмі є табличка 3 медіанним круговим значенням ЕПР, оскільки саме ці значення ЕПР використовуються при розрахунках дальності виявлення цілей радіолокаторами кругового огляду. Аналогічним чином розраховуються кругові ЕПР для інших типів БПЛА. В табл. 2 занесені усереднені дані кругових медіанних значень ЕПР для різних класів БпЛА в тих частотних діапазонах, в яких працюють оглядові РЛС РТВ. 


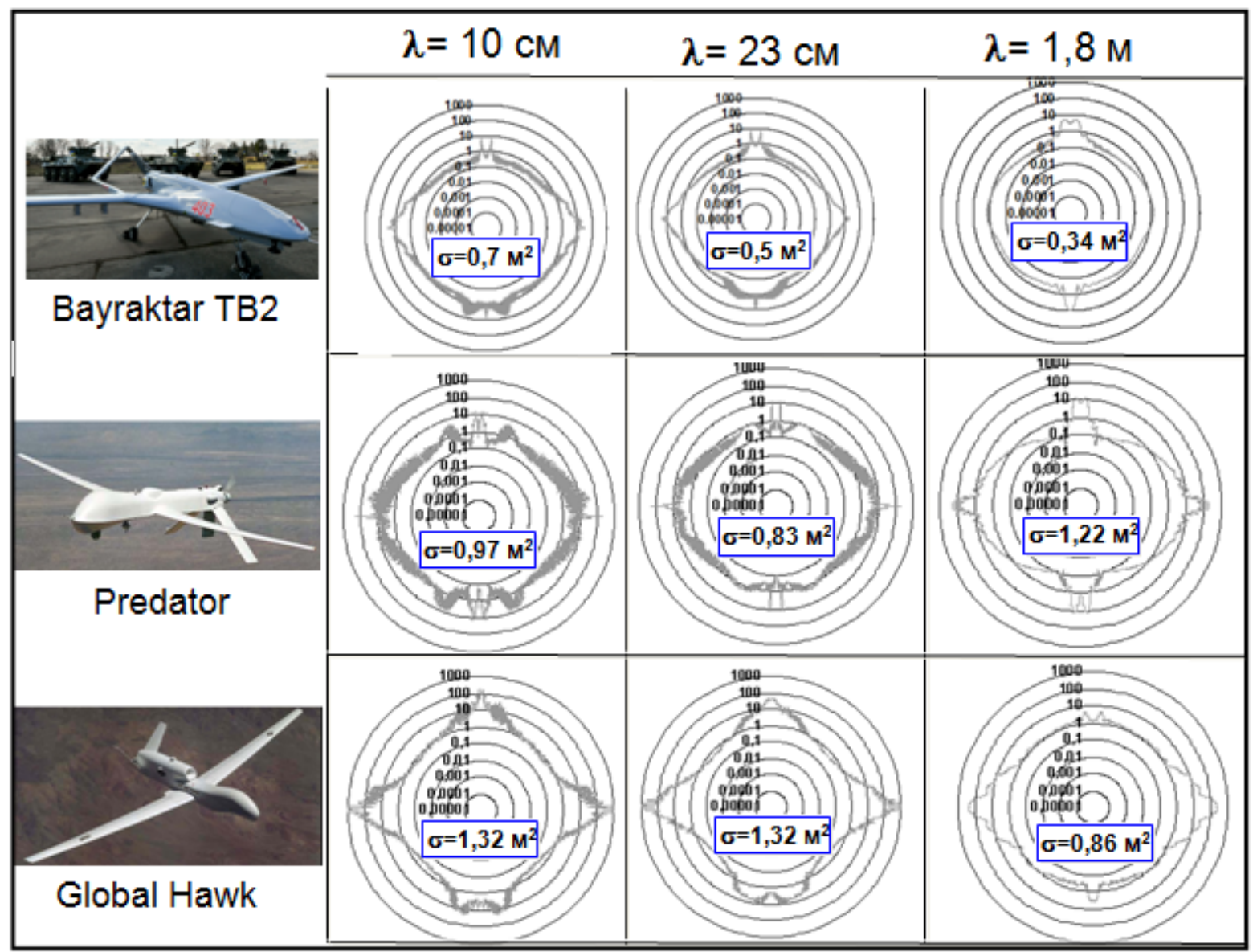

Рис. 1. Кругові ЕПР і медіанні значення ЕПР оперативних і стратегічних БПЛА в діапазонах роботи РЛС РТВ Джерело: розроблено авторами з використанням [20].

Таблиця 2

Усереднені дані кругових медіанних значень ЕПР для різних класів БпЛА

\begin{tabular}{|c|c|c|c|}
\hline $\begin{array}{c}\text { Клас } \\
\text { БПЛА }\end{array}$ & $\begin{array}{c}\text { Рівень } \\
\text { застосування }\end{array}$ & Тип БПЛА & $\begin{array}{l}\mathrm{E} \mathrm{M}^{2}, \\
\end{array}$ \\
\hline \multirow{3}{*}{ I клас } & $\begin{array}{c}\text { мікро } \\
\text { (тактичні) }\end{array}$ & $\begin{array}{l}\text { Mavic-PRO, } \\
\text { “Квадрокоптер” }\end{array}$ & 0,001 \\
\hline & $\begin{array}{c}\text { міні } \\
\text { (тактичні по- } \\
\text { ля бою) }\end{array}$ & $\begin{array}{c}\text { “Гранат-1”, } \\
\text { “Тахион”, } \\
\text { “Иркут-2М”, } \\
\text { “Иркут-3”, “Zala”, } \\
\text { “'Застава”, } \\
\text { “Элерон-3”, } \\
\end{array}$ & 0,01 \\
\hline & $\begin{array}{c}\text { малі } \\
\text { (тактичні) }\end{array}$ & $\begin{array}{l}\text { “Гранат-4”, } \\
\text { “Орлан-10”, }\end{array}$ & 0,03 \\
\hline II клас & $\begin{array}{c}\text { оперативно- } \\
\text { тактичні }\end{array}$ & “Форпост”, & 0,1 \\
\hline \multirow[t]{2}{*}{ III клас } & оперативні & $\begin{array}{l}\text { “Орион”, } \\
\text { “Bayraktar”, } \\
\text { "Predator" }\end{array}$ & 0,5 \\
\hline & стратегічні & "Global Hawk" & 1 \\
\hline
\end{tabular}

Джерело: розроблено авторами 3 використанням даних [20-21].

Зазначені в табл. 2 дані щодо ЕПР БпЛА можна використовувати в подальшому для оцінювання по- тенційних можливостей оглядових РЛС щодо їхнього виявлення і супроводження.

2. Аналіз спроможностей оглядових РЛС щодо виявлення та супроводження БпЛА.

Оскільки категорія БПЛА охоплює досить широке коло літальних апаратів, то аналіз спроможностей оглядових РЛС щодо їхнього виявлення доцільно провести окремо для кожного класу БпЛА.

Радіолокаційне виявлення й супроводження БПЛА стратегічного та оперативного рівня застосування (БпЛА III класу) проблем не викликає, оскільки вони, як об'єкти радіолокації, за своїми характеристиками майже не відрізняються від пілотованих літаків тактичної авіації. Щодо можливостей виявлення та супроводження БпЛА стратегічного застосування, то вони визначаються формулярними даними оглядових РЛС, які визначають параметри зон виявлення саме літаків тактичної авіації. Це практично підтверджується чисельними процедурами супроводження стратегічних БПЛА “Global Hawk", які здійснюють польоти над територією України за програмою "Відкрите небо". Параметри зон виявлення оперативних БПЛА будуть незначною мірою відрізнятись від формулярних даних РЛС, оскільки їхня ЕПР $є$ в середньому вдвічі меншою, ніж в БпЛА стра- 
тегічного рівня. Дальність виявлення БпЛА оперативного рівня застосування буде меншою, ніж формулярні значення РЛС щодо дальності виявлення цілей на середніх і великих висотах на $(15 \ldots 20) \%$, а на малих та гранично малих висотах - на (10...15)\%.

Для виявлення та супроводження БпЛА оперативно-тактичного рівня застосування (БПЛА ІІ кла-
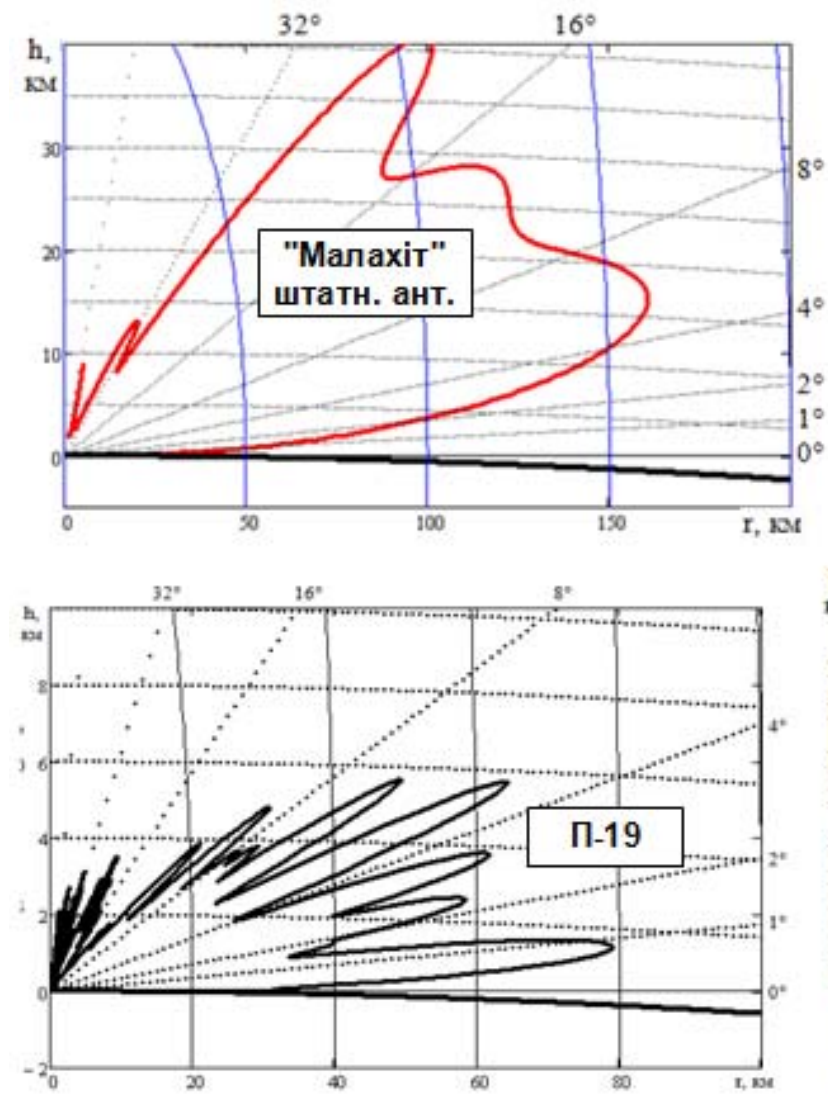

Рис. 2. Зони виявлення оперативно-тактичних БпЛА оглядовими РЛС РТВ Джерело: розроблено авторами з використанням [23, рис. 3-5].

В цілому можливості 3 виявлення оперативнотактичних БпЛА радіолокаційними станціями, що перебувають на озброєнні РТВ, відповідають їхнім можливостям з виявлення крилатих ракет. Супроводження означених БпЛА маловисотними РЛС типу П-19, 19Ж6, 35Д6 може здійснюватись 3 провалами при польоті їх на висотах більше, ніж 2 км.

Найбільш складним завданням $є$ виявлення та супроводження тактичних (малих, міні- $i$ мікро-) БПЛА (БПЛА 1 класу). Складність визначається особливостями означеного класу літальних апаратів, як радіолокаційних цілей.

По-перше, вони мають надзвичайно низьку радіолокаційну замітність через малі фізичні розміри та використання для їх побудови композитних матеріалів. Ефективна поверхня розсіювання БпЛА цього класу є в сотні разів меншою, ніж ЕПР пілотованих літальних апаратів тактичної авіації (див. табл. 2). Внаслідок цього зона виявлення таких цілей оглядо-
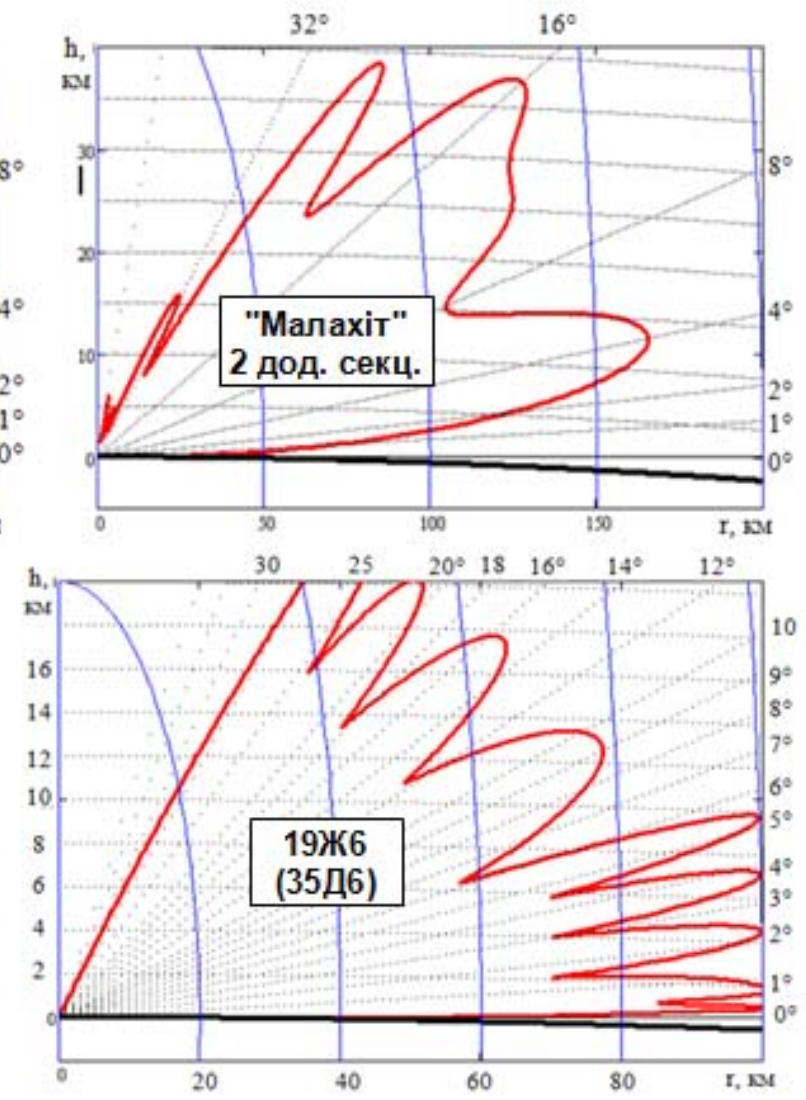

су) характерним є суттєве стискання зон виявлення цілей оглядовими РЛС майже вдвічі. Це підтверджується розрахунками [23] зон виявлення оперативнотактичних БПЛА радіолокаційними станціями "Малахіт”, $19 Ж 6$ (35Д6) та П-19 (рис. 2), які використовуються для інформаційного забезпечення військ в зоні проведення ООС.

вими РЛС стискається майже вдесятеро порівняно 3 формулярними даними РЛС (рис. 3).

По-друге, тактичні БпЛА (особливо міні- та мікро-БпЛА) здійснюють польоти на малих та гранично малих висотах, через що їхнє виявлення майже завжди здійснюється на фоні віддзеркалень від місцевих предметів. Для оглядових РЛС РТВ з їхнім високим енергетичним потенціалом, радіус дії віддзеркалень від місцевих предметів навіть для рівнинної місцевості становить 15...20 км, а для середньопересіченої місцевості доходить до 30...40 км [23], тобто фактично перекриває всю зону виявлення БПЛА (див. рис. 3)

По- третє, тактичні БпЛА мають малу швидкість польоту, яка не перевищує 40 м/с, а БпЛА вертольотного типу взагалі можуть зависати в повітрі. Сама по собі мала швидкість польоту не є критичним недоліком для виявлення цілей, якщо таке відбувається у вільному просторі. Але за наявності пасивних перешкод, створюваних місцевими предметами (а вияв- 
лення тактичних БпЛА завжди здійснюється, як наведено вище, на фоні віддзеркалень від місцевих предметів) мала швидкість польоту цілей різко погіршує можливості їхньої селекції на фоні перешкод.

В цілому можливості оглядових РЛС РТВ щодо
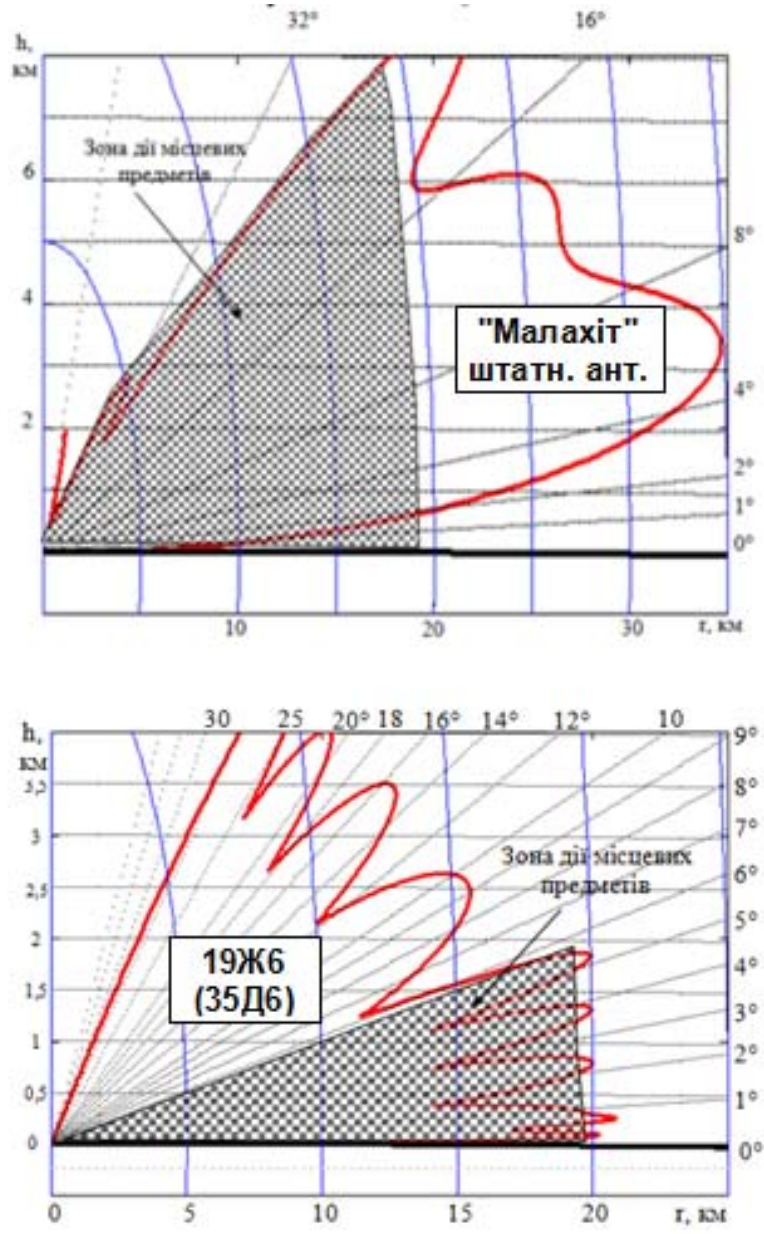

виявлення та супроводження тактичних БпЛА надзвичайно обмежені і використання їх для вирішення означених задач $є$ недоцільним ні з тактичних, ні 3 економічних міркувань.
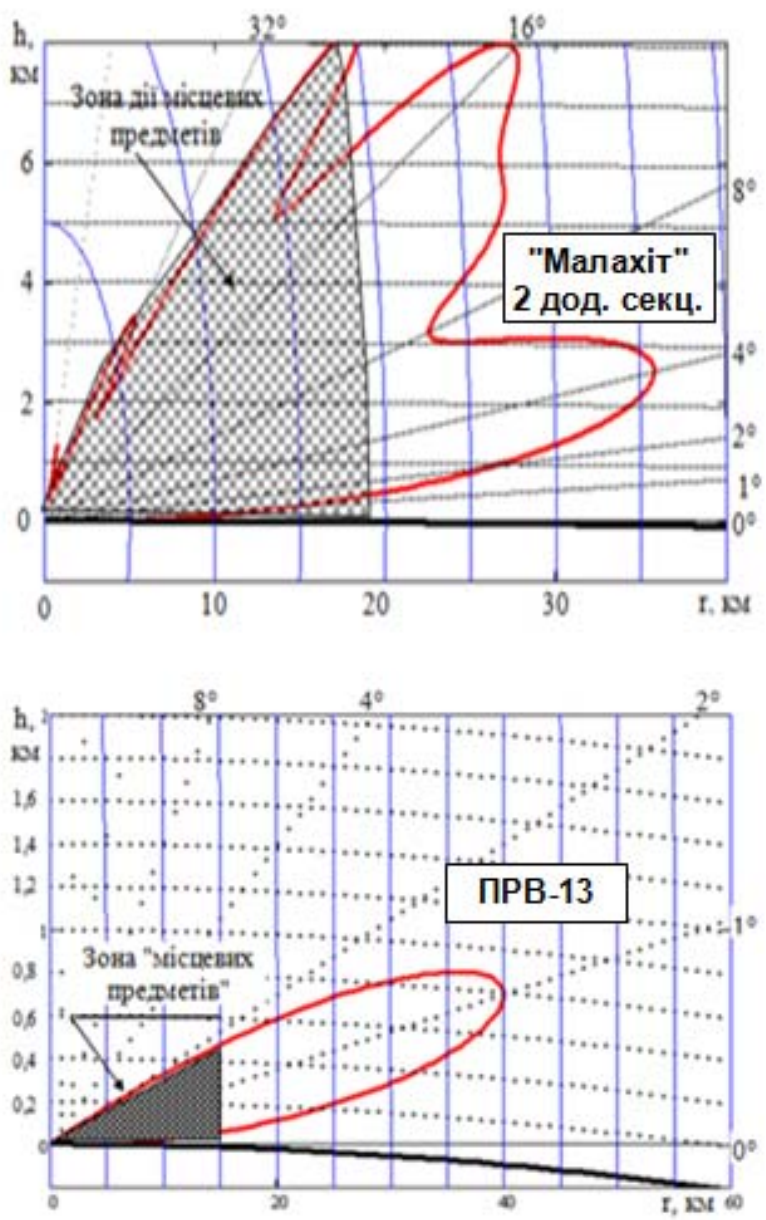

Рис. 3. Зони виявлення міні-БпЛА оглядовими РЛС РТВ Джерело: розроблено авторами з використанням [23, рис. 7-9; 12].

3. Аналіз спроможностей оглядових РЛС щодо ідентифікації БпЛА.

Ідентифікація виявлених БПЛА може здійснюватися переважно за траєкторними ознаками, оскільки спеціальної апаратури розпізнавання об'єктів оглядові РЛС РТВ на теперішній час не мають. При цьому ідентифікація класу БПЛА здійснюється за наступними ознаками:

- дальність виявлення цілі;

- висота польоту цілі;

- швидкість польоту цілі;

- характер траєкторії польоту цілі.

Порівняння траєкторних ознак виявленої цілі 3 льотно-технічними характеристиками БПЛА дає можливість відрізняти клас виявленого об'єкта. Узагальнені орієнтовні льотно-технічні характеристики деяких БПЛА різних класів наведено в табл. 1.

За результатами аналізу табл. 1 видно, що за да- льністю виявлення цілі, висотою і швидкістю польоту можна впевнено вирізнити БПЛА типу “Форпост” та “Орион”. Для тактичних мікро БПЛА характерними $є$ мала дальність виявлення цілей, короткочасність польоту і малий радіус дії. По характеру траєкторії можна вирізнити БПЛА літакового типу, для яких характерними є постійна швидкість польоту, і БПЛА вертолітного типу, які можуть “зависати” над об’єктами розвідки. Таким чином, використання оглядових РЛС РТВ для ідентифікації БПЛА може дати лише частковий ефект з визначення класу БПЛА за траєкторними ознаками.

\section{Висновки}

1. Можливості РЛС РТВ з виявлення та супроводження БПЛА стратегічного рівня застосування визначаються формулярними даними оглядових РЛС щодо виявлення літаків тактичної авіації. 
2. Зони виявлення БПЛА оперативного рівня застосування оглядовими РЛС РТВ стискаються на середніх і великих висотах на (15...20) \%, а на малих та гранично малих висотах - на $(10 \ldots 15) \%$.

3. Виявлення та супроводження БПЛА оперативно-тактичного рівня застосування характеризується стисканням зон виявлення цілей оглядовими РЛС майже вдвічі.

4. Найбільш складним завданням для оглядових РЛС РТВ є виявлення та супроводження тактичних (малих, міні- $і$ мікро-) БПЛА. В цілому можливості оглядових РЛС РТВ щодо виявлення та супроводження тактичних БПЛА надзвичайно обмежені i використання їх для вирішення означених задач $€$ недоцільним ні з тактичних, ні з економічних міркувань.

5. Використання оглядових РЛС РТВ для ідентифікації БПЛА може дати лише частковий ефект 3 визначення класу БПЛА за траєкторними ознаками.

\section{Список літератури}

1. Schwartz Mark R. Airland Battle Doctrine. Modern war. Jul-Aug 2013. \#6. P. 28-31.

2. Karpowicz J. Warfare Use of Unmanned Aerial Vehicles. Safety\&Defense. 2021. No. 7(2). P. 51-64. https://doi.org/ 10.37105/sd.135.

3. Bayramov A. A., Hashimov E. G., Nasibov Y. A. Unmanned Aerial Vehicle Applications for Military GIS Task Solutions. Advances in Mechatronics and Mechanical Engineering. P. 273-296. http://dx.doi.org/10.4018/978-1-5225-7709-6.ch010.

4. Волков А. Ф., Лезік О. В., Корсунов С. І., Левагін Г. А., Яновський О. В., Івахненко К. В. Аналіз застосування БПЛА у вірмено-азербайджанському воєнному конфлікті та можливі шляхи боротьби з ними. Системи озброєння $i$ військова техніка. 2020. № 4(64). С. 7-17. https://doi.org/10.30748/soivt.2020.64.01.

5. Prisakariu V., Muraru A. Unmanned aerial vehicles (UAVs) in the context of modern warfare. Scientific research and education in the Air Force. 2016. No. 18(1). P. 177-184. http://dx.doi.org/10.19062/2247-3173.2016.18.1.23.

6. Glade D. Unmanned Aerial Vehicles: Implications for Military Operations. Alabama : AU PM AFB, 2000. 38 p.

7. Харченко О. В., Кулєшин В. В., Коцуренко Ю. В. Класифікація та тенденції створення безпілотних літальних апаратів військового призначення. Наука і оборона. 2005. № 1. С. 47-54.

8. ДСТУ В 7371:2020. Апарати літальні безпілотні. Основні терміни та визначення понять. Класифікація.

9. Kartashov V., Pososhenko V., Voronin V., Kolesnik V., Kapusta A., Rybnikov N., Pershin E. Methods for detectionrecognition of radar, acoustic, optical and infrared signals of unmanned aerial vehicles. Radiotekhnika. 2021. No. 2(205). P. 138-153. https://doi.org/10.30837/rt.2021.2.205.15.

10. Соловьев В. А., Купреев А. В., Жендарев М. В., Якименко И. В. Проблемы обнаружения беспилотных летательных аппаратов оптико-электронными устройствами. Электронный математический и медико-биологический журнал. 2011. T. 10. Вып. 3. URL: http://www.smolensk.ru/user/sgma/MMORPH/N-31-html/solovjov/solovjov.htm.

11. Tikhonov V. A., Kartashov V. M., Oleinikov V. M., Leonidov V. I. Detection-Recognition of Unmanned Aerial Vehicles using the Composed Auto-Regression Model of their Acoustic Radiation. Visnyk NTUU KPI Seriia Radiotekhnika Radioaparatobuduvannia. 2021. (81). P. 38-46. https://doi.org/10.20535/RADAP.2020.81.38-46.

12. Филин Е. Д., Киричек Р. В. Методы обнаружения малоразмерных беспилотных летательных аппаратов на основе анализа электромагнитного спектра. Информационные технологии и телекоммуникации. 2018. Т. 6. № 2. С. 87-93.

13. Stary V., Krivanek V., Stefek A. Optical detection methods for laser guided unmanned devices. Journal of Communications and Networks. 2018. Vol. 20. No. 5. P. 464-472. https://doi.org/10.1109/JCN.2018.000071.

14. Andraši P. Night-time detection of uavs using thermal infrared camera. Transportation Research Procedia. 2017. Vol. 28. P. 183-190.

15. Sedunov A., Salloum H., Sutin A., Sedunov N., Tsyuryupa S. UAV Passive Acoustic Detection. 2018 IEEE International Symposium on Technologies for Homeland Security (HST). https://doi.org/10.1109/ths.2018.8574129.

16. DJI AEROSCOPE. DJI : web site. URL: https://www.dji.com/aeroscope/info. (accessed 02.07.2021).

17. Moses A., Rutherford M. J., Valavanis K.P. Radar-based detection and identification for miniature air vehicles. IEEE International Conference on Control Applications. Denver, CO, USA. September 28-30, 2011. P. 933-940.

18. Pham T., Srour N. TTCP AG-6: Acoustic detection and tracking of UAVs. U.S. Army Research Laboratory. Proc. of SPIE. 2004. Vol. 5417. P. 24-29.

19. Про затвердження Правил виконання польотів безпілотними авіаційними комплексами державної авіації України : Наказ МО України №661 від 08.12.2016.

20. Сухаревський О. І., Василець В. О., Нечитайло С. В. Довідник характеристик розсіювання повітряних та наземних радіолокаційних об’єктів. Харків : ХНУПС, 2019. 304 с.

21. Сухаревський О. І., Василець В. О., Ряполов І. С. Оцінювання параметрів зон виявлення безпілотного літального апарату “Орлан-10” радіолокаційними засобами самохідного зенітного ракетного комплексу 9К33М3 “Оса-АКМ”. Наука і техніка Повітряних Сил Збройних Сил Украӥни. 2016. № 4(25). С. 33-38.

22. Sukharevsky O., Orlenko V., Vasylets V., Ryapolov I. Radar scattering characteristics of a UAV model in X-band. IET Radar, Sonar \& Navigation. 2020. Vol. 14. Issue 4. P. 532-537.

23. Вишневський С. Д., Бейліс Л. В., Климченко В. Й. Потенційні можливості РЛС РТВ з виявлення оперативнотактичних та тактичних безпілотних літальних апаратів. Наука і техніка Повітряних Сил Збройних Сил Украӥни. 2017. № 2(27). C. 92-98. 
Надійшла до редколегії 16.08.2021

Відомості про авторів:

Пєвцов Геннадій Володимирович

доктор технічних наук професор

заступник начальника Харківського національного

університету Повітряних Сил ім. І. Кожедуба

3 наукової роботи,

Харків, Україна

https://orcid.org/0000-0002-0426-6768

Олещук Микола Миколайович

Командувач Повітряних Сил Збройних Сил України, Вінниця, Україна

https://orcid.org/0000-0001-9737-6896
Information about the authors:

Hennadii Pievtsov

Doctor of Technical Sciences Professor

Deputy Head

of Ivan Kozhedub Kharkiv National

Air Force University in Science,

Kharkiv, Ukraine

https://orcid.org/0000-0002-0426-6768

Mykola Oleschuk

Commander of the Air Forces of the Armed Forces of Ukraine,

Vinnytsia, Ukraine

https://orcid.org/0000-0001-9737-6896

\title{
АНАЛИЗ ВОЗМОЖНОСТЕЙ ОБЗОРНЫХ РЛС РТВ ПО ОБНАРУЖЕНИЮ, СОПРОВОЖДЕНИЮ И ИДЕНТИФИКАЦИИ БЕСПИЛОТНЫХ ЛЕТАЛЬНЫХ АППАРАТОВ
}

\author{
Г.В. Певцов, Н.Н. Олещук
}

Проведен анализ возможностей существующих на вооружении радиотехнических войск Воздушных Сил Вооруженных Сил Украины обзорных РЛС по обнаружению, сопровождению и идентификации беспилотных летательных аппаратов (БПЛА). С учетом опыта ведения боевых действий приведены максимально возможные дальности обнаружения БПЛА с различными ЭПР. Показано, что находящиеся на вооружении радиолокационные средства потенциально способны выявлять оперативно-тактические БПЛА в пределах своих тактико-технических характеристик.

Ключевые слова: беспилотный летательный аппарат, радиотехнические войска, обнаружение, идентификация.

\section{THE ANALYSIS OF THE CAPABILITIES OF THE SURVEILLANCE RADAR STATIONS OF THE RADIO-TECHNICAL TROOPS FOR DETECTING, TRACKING AND IDENTIFYING OF UNMANNED AERIAL VEHICLES}

H. Pievtsov, M. Oleschuk

The characteristics of modern warfare are the wide use of unmanned aerial vehicles (UAVS) and the continued expansion of the range of their tasks. Further development of artificial intelligence technologies will lead to an increase in the use of UAVs in future military operations. Therefore, the search for effective methods for detecting, tracking and identifying UAVs using existing and new promising means is a rather urgent problem. Among the currently known methods for detecting, tracking and identifying $U A V s$, the radar method is the most expedient and makes it possible to ensure the identification of UAVs at significant distances without significant influence of weather conditions and time. The article contains the analyzes of the capabilities of surveillance radar stations in service with the radio-technical troops of the Air Forces of the Armed Forces of Ukraine to detect, track and identify UAVs. Taking into account the experience of warfare, the maximum possible detection ranges for UAVs with different radar cross-section are given. It is shown that the radar systems in service are potentially capable of detecting operational-tactical UAVS within the limits of their performance characteristics. At the same time, only Odd Pair and Odd Group specialized radars are capable of solving problems of detecting mini-UAVs. However, the joint implementation of tasks to identify mini-UAVs with the main tasks for the solution of which these radars are intended is impossible. The detection of UAVs such as IAI Searcher, "Opuou", "Орлан-10", "Орлан-30" at altitudes of more than 5000 meters by radar aids of radio-technical troops is possible and can be implemented at ranges from tens of kilometers (З5Д6 and 19Ж6 radar systems) to 100 kilometers (Spoon Rest D), for the declared performance characteristics.

Keywords: unmanned aerial vehicle, radio-technical troops, detecting, tracking, identifying. 